\title{
Private Initiatives
}

\section{for Development}

I THE ROLE OF PRIVATE INVESTMENT OVERSEAS

by Maurice Zinkin*

At first sight it might seem that private investment is the obvious way of meeting a very large number of the problems of development.

The developing countries are short of capital. The private investor provides it. The developing countries are short of many modern business skills. The private investor provides them. Expected rates of return on capital in the developing countries are high. The private investor from elsewhere brings them down. Tax evasion in the developing countries is frequent. The foreign investor tends to pay his taxes, especially if he comes from countries like those of North America and most of Western Europe, where avoidance may be permissible but evasion, on the whole, is not.

One would therefore have thought that the first objective of every developing country would have been to get itself more foreign private investment. And indeed in the 19 th century that was so. The United States, Canada and Australia, for example, all sought very eagerly for the money of the European saver. It is only half so today. On the one hand, developing countries will offer tax concessions to tempt the private investor in, some of which are so large as to be excessive. On the other hand, having got them in, they all too of ten do not let him run his business in the way he considers most efficient, tax him to an

* Head of the Economics and Statistics Department of Unilever. 
extent which more than counter-balances the value of any initial concessions, and not infrequently nationalise him, with or without adequate compensation.

Such schizophrenia suggests that there is a profound ambivalence in the minds of many host countries about the role of foreign private invest. ment within their borders. This contrasts with the attitude of the foreign private investor himself, who is normally quite clear what he is doing. He invests when he believes that he has some combination of advantages which makes him better able than other people to satisfy some demand at a profit, perhaps also to recognise a demand which other people had not realised was there. The combination may be of various sorts; many variations can be played on, such as capital, skill, research, marketing experience, knowledge of exploration and operational research. But if the investor does not believe, whether rightly or wrongly, that he has some such advantage, he will not invest.

It is, of course, true that the more restrictive the policy of the host country is, the easier it is for any private investor who does get the permission to invest to have some unique combination of advantages and therefore to make a profit. The restrictiveness of the policy is itself likely to have scared off most of his more capable competitors.

The exact mix of advantages will vary from case to case. Some foreign investors, for example, have better access to capital than most governments. It is easier for IBM or Shell to raise one hundred million dollars in the American or West European market than it is for the average African government. But there are plenty of businesses who might very usefully make some small investment for whom one million dollars is 
a large amount of money. Again, the large international companies normally have at their disposal management skills covering a very wide range, though the range is never infinite.

IBM would be as unlikely to go into processed cheese as Kraft would be to go into computers. Some companies have unique knowledge of certain consumer markets, others are high-quality precision engineers. Governments - and, in many countries, local investors too - may know as little about the selling of detergents as they do about micro-electronics.

The local government or the local investor may be able to match individual advantages of the private investor. If the project is not specially large, there may be no great difficulty about raising capital. If the number of skilled managers required is small, it may be possible to hire them in the market or get them as technical aid. If the consumers are within the country itself, the local government or investor should have no insuperable problems in learning how to do suitable market research (it takes longer to learn how to do it in export markets).

What the foreign investor therefore essentially contributes is two things.

First, if the country is short of capital or management or both overall (and the countries which are thus short certainly include Canada and Australia, and almost certainly the UK), then the foreign investor provides a useful supplement.

Much more important, however, is his other contribution, the unique mix of money, people and experience which has enabled him to succeed in his own country. The value of this mix is frequently underestimated in developing countries, 
and indeed in the developed countries, too, because government officials and academics tend to be much less aware of its uniqueness than businessmen are.

The reason why businessmen are usually fairly slow to expand out of fields they know, and why, when they do expand they so often begin by acquiring some company in the new field, is that they are painfully aware of the horrible losses which can be incurred by those who try a new mix wi thout having procured for themselves all the necessary ingredients. One may know all about how to write programmes for teaching machines, but if one knows nothing about selling them to local education authorities (which is a rather special skill) or about the prejudices of teachers, one is unlikely to make money out of programmed learning. One may have a very good engineering research team, but if one does not understand craft unions, one may have great difficulty getting into production. One may have an admi rable formula for a convenience food and yet fail because one does not know that what the housewife uses this convenience food for is a base for something much more elaborate. One may have an intermediate chemical admirably suited for a wide range of purposes and yet fail because one does not have a technical staff qualified to discuss the process problems with the customer. And so on. When one talks of a firm having experience in a particular business, one means that it has already made and paid for a large proportion of the possible mistakes.

If there is a local investor, or for that matter, a local government with exactly or even approximately the same mix of advantages as the foreign investor, it is unlikely that the foreigner will wish to invest at all. One is always handicapped when operating in a society which is not one's own, and one can only get over that disadvantage if one has something which the 
locals have not got. The foreign investor's problem is that the locals so of ten regard it as somehow unfair or improper that he should have that advantage. If, for example, he can raise money more cheaply than anybody can locally, this is frequently considered to be unfair. If he can bring in a team of managers covering all the necessary skills and nobody locally can get an equivalent team because neither the government nor the local investor can of fer an equally attractive career, then this is seen as almost sinister - the foreign investor's government ought somehow to provide the team on technical aid and if it does not, then this is clearly some variety of imperialism. Indeed, the great advantage of Russian aid to most developing countries is that the Russian Government can, in certain limited fields, provide alternative teams.

One is therefore driven to some very simple but not very satisfactory conclusions. The obvious policy with foreign private investment is to let it take its chance. If it has something to contribute, it will make money; if it has not, it will not. This is, on the whole, the policy of the strongest country of all, the United States. When countries do not do this, as many countries in Europe, let alone in the developing world do not, it does not mean that the private foreign investor would not bring economic development with him. It only means that he would also bring with him something else that the host country does not like. It may be that he is suspected of having greater negotiating skill than local officials or that he is more competitive than local businessmen or that his advertisements are regarded as vulgar or that the standards of personal behaviour of his top management are considered too permissive. 
There may be many reasons, but they could probably all be summarized into two. Either it is thought the foreign private investor will bring with him social changes that the local governing classes (or perhaps the local revolutionaries) do not like, or it is felt that he will be too efficient and therefore obtain too many of the top positions in the local society. How valid these fears are vary from case to case. How much one agrees with them probably depends on whether or not one likes the local governing classes (or the local revolutionaries) and their values. What one has to do in every case is to weigh these economic gains against the inevitable economic losses of restriction when one comes to consider under what conditions foreign private investment should be allowed to operate. 